\title{
Students' achievement and opinions on the implementation of e-learning for phonetics and phonology lectures at Airlangga University
}

\author{
Deny A. Kwary ${ }^{1}$ \\ Sarah Fauzie ${ }^{1}$
}

\section{Abstract}

The demand of e-learning at higher education has increased significantly in the past several years. In Indonesia, the implementation of e-learning has been encouraged by the government since 2011. However, universities are still looking for the most appropriate e-learning system, and unsure of the effectiveness of e-learning program. This paper discusses the implementation of e-learning system at Airlangga University, one of the top five state-owned universities in Indonesia. The e-learning system implemented in this university follows the Seven Principles of Good Practice in Undergraduate Education, i.e. encourage contacts between student and faculty; develop reciprocity and cooperation among students; use active learning techniques; give prompt feedback; emphasize time on task; communicate high expectations; and respect diverse talents and ways of learning. The e-learning platform at this university is called AULA (Airlangga University e-Learning Application). The respondents of this study were the students who took the General Linguistics course, particularly for the lectures on Phonetics and Phonology. Based on the t-test calculation of the exam scores, we conclude that there is no significant difference between the results of the e-learning and those of the classroom learning. The results of questionnaires show that $85 \%$ of the students are satisfied with the implementation of e-learning as they think that the e-learning makes it easier for them to understand the materials, it is fun, and is convenient to access. For further implementation, the students suggested the additions of podcasts and games, more time for the quizzes, and improvement of the e-learning platform.

\section{Keywords}

Learning - Classroom learning - E-learning - Phonetics - Phonology.

1- Universitas Airlangga, Indonesia. Contacts: d.a.kwary@fib.unair.ac.id; sarahrimaf@yahoo.com 


\section{Resultados e opiniões dos alunos sobre a implantação do ensino a distância em aulas de fonética e fonologia na Universidade Airlangga}

\section{Resumo}

A demanda por ensino a distância no ensino superior tem aumentado significativamente nos últimos anos. Na Indonésia, sua implantação vem sendo estimulada pelo governo desde 2011. No entanto, as universidades ainda buscam o sistema mais apropriado e permanecem inseguras sobre a eficácia do programa. Este artigo discute a implantação do sistema de ensino a distância na Universidade Airlangga, uma das cinco principais universidades estatais na Indonésia. O sistema implantado nessa universidade segue os Sete Princípios de Boas Práticas em Educação de Graduação, isto é, incentivar os contatos entre estudantes e professores, desenvolver a reciprocidade e a cooperação entre estudantes, utilizar técnicas ativas de aprendizagem, oferecer devolutivas imediatas, enfatizar o tempo nas tarefas, comunicar aos estudantes o que deles se espera, respeitar os diversos talentos e as várias formas de aprender. A plataforma de ensino a distância nessa universidade é chamada de AULA (Airlangga University e-Learning Application). Os entrevistados do estudo foram os alunos que cursaram Linguistica Geral, particularmente as aulas de Fonética e Fonologia. Com base no cálculo de teste-t dos resultados em provas, concluimos não ter havido diferença significativa entre os resultados da educação a distância e os de ensino presencial. Os resultados dos questionários mostram que 85\% dos alunos estão satisfeitos com a implantação do ensino a distância, por acreditarem que o sistema facilita a compreensão dos materiais, é divertido e de acesso conveniente. Para novas implantações, os alunos sugeriram podcasts e jogos, além de um tempo maior para responder aos questionários e melhorias na plataforma.

\section{Palavras-chave}

Aprendizagem - Ensino presencial - Educação a distância - Fonética - Fonologia.

\section{Introduction}

The advances in information technology have encouraged the use of Internet in education. At the moment, a number of universities in the world have implemented e-learning in response to the high demand of the program and as an effort to make education more accessible to the wider population. In Indonesia, e-learning or distance education has been encouraged since 2011 with the issuance of the education minister's decree (Keputusan Menteri Pendidikan Nasional - kepmendiknas) No: 107/U/2001. In that 
decree, e-learning or distance education is defined as the education program in which the learning process is conducted in a long distance through the use of any communication media. That definition is similar to the one given by Keegan (1998), that e-learning or distance education is the process of teaching where interaction between teachers and students is limited because teachers and students are separated in terms of time and space.

One of the reasons put forward by the government to encourage the implementation of e-learning is to achieve the national target of APK (Target 2015, Angka Partisipasi Kasar) (KEMENDIKBUD, 2015) for university students. APK refers to the proportion of the number of university students in comparison with the number of people who have graduated from senior high schools. According to the data from the Ministry of Education and Culture (http://www.kemdikbud.go.id), the APK in 2012 was 28\%, and in 2015 it has increased to 35\%. This means that in 2015 there were 35\% of graduates from senior high schools who studied in universities. This can be partly due to the increase in the use of e-learning that has enabled several universities to accept more students. The Directorate General of Higher Education (DIKTI) believes that by offering courses via e-learning, the number of people studying in Indonesian universities will increase rapidly. The government expects that by 2045 the APK will have reached 60\%.

The e-learning system was implemented almost half a century ago in other countries, notably in England and the United States. In England, e-learning was implemented in 1970 and has been developing rapidly until now. In the United States, e-learning is also the choice of millions of people. The number of universities that offer e-learning in the lectures has increased rapidly. The 2011 Survey of Online Learning reveals that the number of students taking at least one online course has surpassed 6 million. Back in 2011, nearly one third of all students in higher education are taking at least one online course Going the distance: online education in the United States, 2011 (ALLEN; SEAMAN, 2011).

In e-learning or distance education (these two terms are used interchangeably in this article), the places of the teacher and the learners are separated but the teacher and the learners can use Web-Based instructions to meet. On the other hand, classroom learning, often referred to as 'traditional learning', can be defined as face-to-face, classroom-based teaching that typically occurs between student/teacher, student/student, student/content, and teacher/content (ANDERSON, 2003). In this article, the term 'classroom learning' is used interchangeably with the term 'traditional learning' since several researchers have used both terms to refer to the same thing. However, this does not mean that classroom learning is always traditional, since some innovations can also be implemented there. Such innovations will not be discussed here since this is beyond the scope of this study.

Both e-learning and classroom learning have to follow the principles of good practice in education. Chickering and Ehrmann (1996) state the Seven Principles for Good Practice in Undergraduate Students. These seven principles are: (1) Encourage contacts between student and Faculty (2) Develop reciprocity and cooperation among students (3) Use active learning techniques, (4) Give prompt feedback (5) Emphasize time on task (6) Communicate high expectations, and (7) Respect diverse talents and ways of learning. These seven principles can also be used to analyse online education for undergraduate students. 
According to Freeman (2012), the three main factors that affect the quality of the preparation of the program are students, teachers, and curriculum. All three of these factors would need to be considered in the preparation of e-learning or distance education. These factors were also taken into account in the process of designing the e-learning program at the English Department of Airlangga University, Indonesia.

There are several studies that have discussed the comparison between e-learning and classroom learning, cf. Kwary (2006), Awadh (2010), and Alharbi (2012). Kwary (2006) conducted research comparing the results of e-learning and traditional learning in teaching Reading IV subject at the English Diploma Program in Airlangga University. The result was not favourable to e-learning, since the increase of the scores of the students joining the traditional learning was significantly higher than the increase of the scores of the students joining the e-learning. This can be due to the fact that in 2006, there was no e-learning platform, such as Moodle, implemented at Airlangga University. The e-learning materials were very limited, i.e. only PowerPoint files and Multiple-choice questions made by using Hot Potatoes software, and they were placed in the lecturer's personal website and in the computers available in the computer laboratory.

Awadh (2010) discusses the effectiveness of using e-learning, blended learning, and traditional learning implemented at Durham University. This study focused on students' achievement and attitudes. The result shows that there is a statistically significant difference (at the 0.05 level) between the three methods in terms of students' achievement favouring blended learning method, while no statistically significant differences exist (at the 0.05 level) between e-learning and traditional learning in terms of students' achievement. The other study about e-learning was written by Alharbi (2012), who made a comparative analysis of students' perceptions and performance in the Arabic language lessons. He found that students' performance was enhanced through the use a blended learning environment.

Given the recent popularity of e-learning, it is necessary to conduct further research on it in the Indonesian context. This study focuses on the comparison, in terms of academic achievement, between e-learning and classroom learning at the English Department of Airlangga University, Indonesia. Airlangga University is one of the top five stateowned universities in Indonesia. The Indonesian government officially opened Airlangga University as the first higher education institution in East Indonesia on 10 November 1954. When it was first established, it had only five faculties, but now it has increased to 13 faculties, with 127 study programs enrolling more than 20,000 students. One of its study programs takes place in the English department, where this study took place.

At the English department of Airlangga University, the e-learning system was implemented for the Introduction to General Linguistics classes in 2014. However, the e-learning system has not been tested and compared with the classroom learning system. Moreover, there should be a study to compare the results of e-learning and classroom learning systems, considering also the diversity and peculiarity of each system. In addition, a further study should be conducted on the expectations of the students towards the e-learning program, in order to achieve good quality on this program. The result of this research can be used as the basis of the English Department and Airlangga University 
to refine the e-learning system. It can also be the reference to the implementation of e-learning in other faculties at Airlangga University, or even to be the role model for other universities in Indonesia.

\section{The e-learning system and the seven principles of good practice}

The e-learning system implemented at the English Department of Airlangga University follows the Seven Principles of Good Practice in Undergraduate Education by Chickering and Ehrmann (1996). These principles are observed in the process of creating the e-learning materials and setting the courses at the e-learning platform of Airlangga University, called AULA (Airlangga University e-Learning Application). Each principle is explained as follows.

\section{Good practice encourages contacts between students and faculty}

AULA website uses asynchronous communication to interact with the students. Asynchronous communication occurs at varying times, which means that if the students ask about the homework or about the materials given by the lecturer, the lecturer responds some time later, not directly. As Conrad \& Donaldson (2011) state, the asynchronous communication has benefits. The depth of thought in asynchronous activities is usually greater than in synchronous activities. The students can choose to interact or ask questions in their own convenient time. At AULA, the students can send a message to the lecturer if they want to ask something about the materials. The lecturer usually replies to the students' questions 24 hours at the most after the students send the message/question.

\section{Good practice develops reciprocity and cooperation among students}

Good learning, like good work, is collaborative and social, not competitive and isolated. Working in a group can increase involvement in learning. To develop reciprocity and cooperation among students, the lecturer provides a forum where the students can post their opinions or questions, which may be responded by other students and the lecturer. Unfortunately, during the implementation of this e-learning system, the students did not use the forum since it was not compulsory for the students to post comments or questions. In a further development, the lecturer should create a task that requires the students to work together to answer it.

\section{Good practice uses active learning techniques}

In today's learning, the students do not learn much by only sitting and listening to the lectures explaining the materials. In the e-learning system implemented at AULA, the students have to do a quiz after they attend to the lecture (i.e. opening the PowerPoint file and/or reading the PDF file). From this activity, the students can learn and take a quiz 
to build deeper understanding from what they have learned. They also need to obtain a minimum score of 70 . If they have not reached that score, the students can retake the quiz.

\section{Good practice gives prompt feedback}

In addition to the asynchronous communication, where the students can send a message to the lecturer, there is also a specific time allocated by the lecturer for the synchronous communication. In that specific time, the students can chat directly with the lecturer, ask questions, and get the answers or feedback directly. The practice of prompt feedback is also adopted in the quizzes. In AULA website, after the students finish the quizzes, the scores will automatically appear on their screens.

\section{Good practice emphasizes time on task}

Allocating realistic amount of time means effective learning for students and effective teaching for the faculty. Setting a particular time limit to complete a task or a quiz will encourage the students to be disciplined and appreciate their time. This principle is applied in the quizzes that the students have to complete. When the students do a quiz, they will be given only fifteen minutes to finish answering all the questions. If the students cannot finish the task within fifteen minutes, they will lose what they have done, and must do the quiz from the beginning. This means that time is the one of the most important aspects when it comes to completing the quizzes.

\section{Good practice communicates high expectations}

In completing the quiz at the AULA website, the student must reach a minimum score of 70 to be considered present in the e-learning lecture. With this requirement, the students would become more highly self-motivated to reach the minimum expected score. If the student cannot reach the minimum score of 70, he/she can retake the quiz. However, there is also a maximum number of times given to the students to take the quiz. The lecturer will allow the student to take the quiz not more than three times. Consequently, the students have to study well, e.g. reading the PowerPoint slides and/or reading the PDF files provided, before taking the quiz.

\section{Good practice respects diverse talents and ways of learning}

Different students have different ways of learning. Therefore, the lecturer needs to provide various types of materials. For the reading materials, there are PDF files for students who enjoy reading, and PowerPoint files for students who would like to see the summary of the main points. There is also a five-minute webcast, for students who would like to watch a video with an audio. In addition, the quizzes are created in several formats, i.e. multiple choice question, matching, and crosswords. 


\section{Method}

This research uses a mixed-method design, which is called the explanatory sequential design. This means that the research starts with the quantitative approach, and then continues with the qualitative approach to explain further the quantitative findings (CRESWELL. 2003). The quantitative approach is used to test if there is a significant difference between the results of the e-learning and those of the classroom learning systems. The statistical test used is the t-test. Then, the qualitative approach is used to collect the opinion of the students on the e-learning system, by means of interviews with open-ended questionnaires. This will result in suggestions for the improvement of the e-learning system.

The classroom learning was conducted using the traditional method of teaching, i.e. the lecturer gave the explanation using PowerPoint files shown through an LCD projector. During the lecture, the lecturer also gave the students the chance to ask questions about the lecture materials. The e-learning sessions were held at the Airlangga University e-Learning Application, which is usually abbreviated AULA. AULA is based on Moodle platform. The main materials are PowerPoint files, and quizzes. There was also a discussion forum where the students can ask questions to the lecturer. AULA can be accessed from the website www.aula.unair.ac.id (See Figure 1).

Figure 1- Screenshot of AULA's web page.

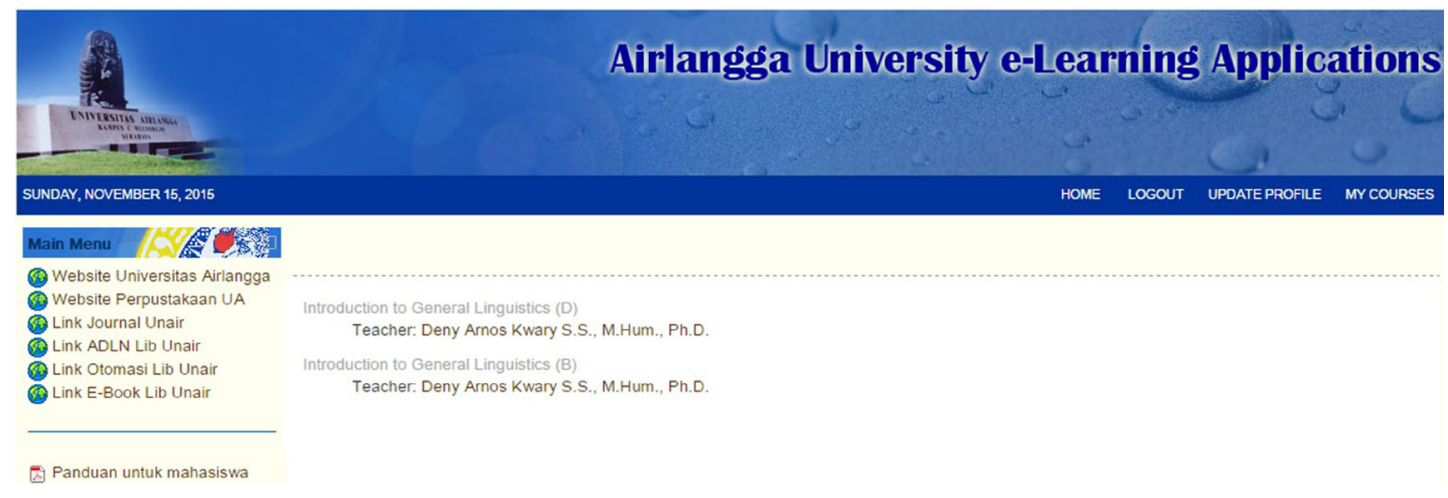

Source: website www.aula.unair.ac.id

The population of this research is the students of the English Department, Faculty of Humanities, Airlangga University. The students admitted to this department are well selected. Every year, there are more than 1,500 students registered, and only 150, who pass the selection exam, are accepted. The selection exam is a combination between the SAT (Scholastic Aptitude Test) and TOEFL (Test of English as a Foreign Language), which have been adapted to the Indonesian context. Considering this rigorous candidate selection process, we can assume that the students in this department have the same 
proficiency level. This department offers various subjects. The subject chosen for this study is the Introduction to General Linguistics because this subject has a large number of students and it is a compulsory subject. In addition, the students have never studied Linguistics in their previous education. Therefore, we can assume that the students have the same level of knowledge in Linguistics.

In 2015, the number of people who enrolled to the Introduction to General Linguistics class was 124 students, who were divided into four classes, called Class A, Class B, Class C, and Class D. There is no difference between these classes as the divisions are simply based on the student registration numbers. Out of the four classes, two classes (Class B and Class D) were chosen because they were taught by the same lecturer. This is necessary to avoid the bias in the teaching styles of different lecturers. The other classes (Class A and Class C) were taught by a different lecturer. In the two classes selected (i.e. Class B and Class D), the research focuses on the topics of Phonetics and Phonology because these were the first topics to be offered with the e-learning format.

In the two classes selected, called class B and class D, the distribution of the sessions are as follows. In the Phonetics lecture, the students of class B joined the lecture via the e-learning platform, while the students of class D had the classroom learning. Next, in the phonology lecture, the students of class B took the lecture in the classroom, whereas students of class D joined the lecture via the e-learning platform. After the sessions were conducted, there was a test to measure the achievement of the students. In addition, openended questionnaires were also distributed to obtain the opinion of the students about the e-learning program that they have joined.

\section{The results of the Phonetics lecture}

As explained previously, the Phonetics lecture was delivered to the students of Class $\mathrm{B}$ in the e-learning format, while the students of Class D joined it in the classroom, i.e. a classroom learning. A week after they followed the lecture, a Phonetics test was given to the students in both classes. The same tests were conducted in a classroom, not in the e-learning platform, so that the lecturer could keep an eye on the students to make sure that no students cheated in the text. The result of the calculation of the scores is shown in Table 1.

As we can see in Table 1, the average score of the thirty-two students of Class B, who joined the e-learning class, was 72.54. There are three students who obtained the perfect score of 100. If we take the score 50 as a middle score, since the range of the score is $0-100$, we can see that 26 students obtained a score higher than 50, and only 6 students obtained 50 or less. This means that the e-learning class has been effective in general.

In Class $\mathrm{D}$, where the students joined the classroom learning, the average score was 72.69, which is only a slight higher than that of Class B. In terms of the perfect score, there are two students who obtained the score 100. If we again take the score 50 as a middle score, since the range of the score is $0-100$, we can see that 24 students obtained a score higher than 50, and only 4 students obtained 50 or less. This means that the classroom learning has also been effective in general. The Standard Deviation 
between these two classes was also quite similar, i.e. 19.12 for the e-learning and 17.61 for the classroom learning.

Table 1- The results of the phonetics lecture.

\begin{tabular}{|c|c|c|c|}
\hline \multicolumn{2}{|c|}{ Class B (e-learning) } & \multicolumn{2}{|c|}{ Class D (classroom learning) } \\
\hline No & Score & No & Score \\
\hline 1 & 64.28 & 1 & 92.85 \\
\hline 2 & 64.28 & 2 & 78.57 \\
\hline 3 & 85.71 & 3 & 57.14 \\
\hline 4 & 92.85 & 4 & 64.28 \\
\hline 5 & 28.57 & 5 & 42.85 \\
\hline 6 & 85.71 & 6 & 42.85 \\
\hline 7 & 50 & 7 & 71.42 \\
\hline 8 & 85.71 & 8 & 57.14 \\
\hline 9 & 78.57 & 9 & 85.71 \\
\hline 10 & 100 & 10 & 85.71 \\
\hline 11 & 85.71 & 11 & 92.85 \\
\hline 12 & 57.14 & 12 & 78.57 \\
\hline 13 & 64.28 & 13 & 85.71 \\
\hline 14 & 85.71 & 14 & 71.42 \\
\hline 15 & 100 & 15 & 78.57 \\
\hline 16 & 85.71 & 16 & 100 \\
\hline 17 & 85.71 & 17 & 100 \\
\hline 18 & 92.85 & 18 & 64.28 \\
\hline 19 & 50 & 19 & 92.85 \\
\hline 20 & 57.14 & 20 & 92.85 \\
\hline 21 & 78.57 & 21 & 71.42 \\
\hline 22 & 64.28 & 22 & 78.57 \\
\hline 23 & 50 & 23 & 42.85 \\
\hline 24 & 78.57 & 24 & 64.28 \\
\hline 25 & 35.71 & 25 & 57.14 \\
\hline 26 & 42.85 & 26 & 78.57 \\
\hline 27 & 71.42 & 27 & 42.85 \\
\hline 28 & 100 & 28 & 64.28 \\
\hline 29 & 92.85 & & \\
\hline 30 & 64.28 & & \\
\hline 31 & 71.42 & & \\
\hline 32 & 71.42 & & \\
\hline \multicolumn{2}{|c|}{ Mean: 72.54} & \multicolumn{2}{|c|}{ Mean: 72.69} \\
\hline \multicolumn{2}{|c|}{ SD: 19.12} & \multicolumn{2}{|c|}{ SD: 17.61} \\
\hline
\end{tabular}

Source: Data tabulated by the authors.

In order to determine whether or not there is a significant difference in the achievement of the students of Class B and Class D, we should not look at the means 
only. It is necessary to use a statistical test called a t-test to confirm whether or not the difference is significant. The result of the t-test using the SPSS computer program is 0.614 , which is higher than 0.05 . This means that we can conclude that there is no significant difference between e-learning and classroom learning in the Phonetics lecture.

\section{The results of the phonology lecture}

In the Phonology lecture, the students of Class B took the lecture in the classroom, whereas students of Class D joined the lecture via the e-learning platform. This is different from the case for the Phonetics lecture where the students of Class B joined the e-learning while the students of Class D studied in the classroom. However, similarly to the Phonetics lecture, a test for the Phonology lecture was administered a week after the students followed the lecture. The scores of the test achieved by the students are shown in Table 2 .

Table 2- The results of the phonology lecture.

\begin{tabular}{|c|c|c|c|}
\hline \multicolumn{2}{|c|}{ Class B (classroom learning) } & \multicolumn{2}{|c|}{ Class D (e-learning) } \\
\hline No & Score & No & Score \\
\hline 1 & 71.42 & 1 & 64.28 \\
\hline 2 & 57.14 & 2 & 64.28 \\
\hline 3 & 78.57 & 3 & 78.57 \\
\hline 4 & 92.58 & 4 & 35.71 \\
\hline 5 & 57.14 & 5 & 35.71 \\
\hline 6 & 71.42 & 6 & 35.71 \\
\hline 7 & 57.14 & 7 & 50 \\
\hline 8 & 71.42 & 8 & 78.57 \\
\hline 9 & 57.14 & 9 & 71.42 \\
\hline 10 & 57.14 & 10 & 85.71 \\
\hline 11 & 64.28 & 11 & 78.57 \\
\hline 12 & 100 & 12 & 57.14 \\
\hline 13 & 92.85 & 13 & 85.71 \\
\hline 14 & 78.57 & 14 & 64.28 \\
\hline 15 & 85.71 & 15 & 85.71 \\
\hline 16 & 64.28 & 16 & 78.57 \\
\hline 17 & 71.42 & 17 & 71.42 \\
\hline 18 & 42.85 & 18 & 78.57 \\
\hline 19 & 57.14 & 19 & 57.14 \\
\hline 20 & 71.42 & 20 & 85.71 \\
\hline 21 & 50 & 21 & 85.71 \\
\hline 22 & 57.14 & 22 & 42.85 \\
\hline 23 & 57.14 & 23 & 42.85 \\
\hline 24 & 50 & 24 & 78.57 \\
\hline 25 & 28.57 & 25 & 21.42 \\
\hline 26 & 85.71 & 26 & 64.28 \\
\hline 27 & 57.14 & 27 & 35.71 \\
\hline 28 & 78.57 & 28 & 78.57 \\
\hline 29 & 78.57 & & \\
\hline 30 & 50 & & \\
\hline 31 & 57.14 & & \\
\hline 32 & 50 & & \\
\hline \multicolumn{2}{|c|}{ Mean: 65.61} & \multicolumn{2}{|c|}{ Mean: 64.03} \\
\hline \multicolumn{2}{|c|}{ SD: 15.95} & \multicolumn{2}{|c|}{ SD: 19.39} \\
\hline
\end{tabular}

Source: Data tabulated by the authors. 
As we can see in Table 2, the average score of the thirty-two students of Class B, who joined the classroom learning, was 65.61. There are 26 students who obtained a score higher than 50, and there are only 6 students who obtained the score 50 or less. If we compare these results with the results of the e-learning, i.e. the students in Class $\mathrm{D}$, we can see that the difference is not too big. The students in Class D who joined the e-learning received only a bit lower average score, i.e. 64.03. There are also more students who obtained a score higher than 50, than those who obtained the score 50 or less, i.e. 20 and 8 , respectively.

In the further calculation, i.e. the Standard Deviation, we can see that there was a difference between the SD for Class B and the SD for Class D, although this difference was not too big. The SD for Class B, the classroom learning, is 15.95, whereas the SD for Class $\mathrm{D}$, the e-learning, was 19.39. This means that there is more variety in the scores of the students who joined the e-learning than those who joined the classroom learning for the Phonology lecture. The similar results were also shown in the Phonetics lecture. However, as stated previously, the difference was not very big.

If we only consider the comparison of the means for both the Phonetics lecture and the Phonology lecture, we might conclude that the classes which were conducted with the classroom learning were more successful than those conducted through the e-learning. This is because the means or the average scores obtained by the students joining the classroom learning are higher than those obtained by the students joining the e-learning. There is a possibility that the students enjoyed the classroom learning more than the e-learning. This is in tune with the statement made by Hislop (1999), that traditional classes are more interesting than online classes. In addition, students who learn online must work harder than those in a traditional classroom due to the lack of face-to-face contact.

However, in order to determine whether the difference is significant or not, it is necessary to use the t-test again. The result of the t-test using the SPSS computer program was 0.222 , which is higher than 0.05 . This means that we can still conclude that there is no significant difference between the result of the e-learning and that of the classroom learning in the Phonology lecture. This result is similar to that for the Phonetics lecture.

Since the statistical tests confirm that the differences are not significant, we can say that the e-learning that has been implemented can be considered as effective as the classroom learning. This can be due to the fact that the students are adults and most of them are quite responsible for their own learning. This is in tune with the opinion of Pinker (2007), that adults often depend on the conscious exercise of their considerable intellects. Adults tend to be more disciplined and are often prepared to struggle on despite boredom. In addition, these students are those from the Generation Z, who are also known as the iGeneration, since they were born in the 1990s. According to Rosen, Carrier, and Cheever (2010) the iGeneration students love all the things technological. The e-learning platform at Airlangga University can be accessed conveniently from a laptop, a netbook, and even a hand-held device, such as a smartphone.

If we compare the results of this research and those of Kwary (2006), we can see that there is a different conclusion, although the research location is the same, that is, the English department of Airlangga University. This research shows that there is no significant 
difference between the results of the e-learning and those of the classroom learning. Kwary's research found that the students joining the classroom learning obtained significantly higher scores than the students joining the e-learning. This different conclusion can be due to the development of technology. When Kwary conducted the research in 2006, the students were still required to come to the university to access the materials from the computer laboratory. This is because at that time, only few students had an Internet access at home. The e-learning materials were also very simple, only containing PowerPoint files and Multiple-choice questions. In this current research (conducted in 2015), the students access the AULA website at home. The system makes the students feel comfortable to access the website anywhere and at any time. The learning materials are also more various. The advances in the technologies have enabled the faculty members to create and share useful resources which are more interactive.

\section{The opinions of the students}

After the lectures and the tests were completed, the lecturer interviewed the students and asked them to write their opinions about the e-learning system. The students were asked to answer two main questions, i.e. whether they were satisfied with the e-learning system and why, and what their suggestions are for improving the e-learning system. Based on the recapitulation of the opinions of the students, 51 students were satisfied with the e-learning system, and only 9 students out of 60 students seemed to be unsatisfied with e-learning system. Below is the explanation given by the students who are unsatisfied, followed by the opinions of the students who are satisfied with the e-learning system that has been implemented. Finally, the suggestions of the students are listed and explained as well. The students who are unsatisfied with the e-learning system stated that the e-learning materialslacked detailed explanation and also verbal explanation.

The criticism on the lack of detailed explanation can be solved by providing more materials. In AULA website, the lecturer provides PDF files and PowerPoint files to be studied by the students. The PDF files are the reading text, but these are rarely opened by the students. Most of the students only studied the PowerPoint files which present the main points of the study. This might make the students unable to understand the materials well, because in the PowerPoint files there are only limited number of words which can be written. Consequently, the students have to be encouraged to read the PDF files, so that they can obtain more detailed explanation of the lessons.

The other criticism about the implementation of e-learning is the lack of verbal explanation. This criticism can be solved by providing more files with audios and videos. Kearsley (2000) points out that the most important role of the instructor in online classes is to ensure a high degree of interactivity and participation. The audio and video files can assist in making the lessons more interactive. Actually, the lecturer has provided an audiovideo file for the Phonetics lecture, but it was simply a 5-minute webcast explaining the vowel sounds. In addition to this file, a full lecture should also have been available, so that the students can choose whether to open the PowerPoint file or to open the video lecture file. 
In connection with the previous criticism put forward by the students, lecturers need to realize the different ways on how people learn, so that the lecturers can provide a selection of materials that cater the different ways of learning. According to Bersin (2004), there appears to be three primary ways on how people learn: there are visual learners, auditory learners, and kinaesthetic learners. Students who are categorized as visual learners like to take notes while viewing PowerPoint slides with graphics. Most Internetbased courseware is targeted toward visual learning. Students who are categorized as auditory learners like to listen to lectures. Students who are categorized as kinaesthetic learners are those who learn best through touching and doing things. To cater for the students who are categorized as kinaesthetic learners, the lecturers can provide drawing exercise in the quiz, such as drawing the syllable structure, creating a sound chart, or drawing the places of articulation.

As mentioned previously, 51 students (85\%) out of 60 students were satisfied with the e-learning system. Their reasons for enjoying the e-learning are as follows: it is easy to understand, fun, and easy to access (time and place are flexible).

In the e-learning, the lecturer explains the main points of the lessons by providing PowerPoint files. For some students, reading materials from the PowerPoint files can make them understand the materials better than reading the materials from the textbook. In addition, by using the e-learning at AULA website, these students thought that they could focus more on the materials, as they were not distracted by their classmates. After the students studied the materials presented in the PowerPoint files, they could directly start working on the quiz related to the materials. The quiz enabled the students to check their comprehension of the materials. In the AULA website, after the students finished the quiz, their score would appear automatically. Knowing that they obtained good scores in the quiz made them thought that they had understood the materials.

Some students consider the e-learning as a fun activity. These students mentioned the quizzes which were fun to do. The quizzes were provided in a variety of formats, i.e. multiple choice questions, matching exercises, and crosswords. The crosswords are the particular favourite of most students, as they feel like playing a game instead of doing a quiz. Playing is considered to be an educationally powerful process, in which learning will occur spontaneously (BENNETT; WOOD; ROGERS, 1997).

The other reason for the students to enjoy the e-learning system is the fact that it is easy to access. In comparison to several years ago, when students had to browse the website in the computer laboratory of the faculty, nowadays the students can access the website (i.e. the e-learning platform) at their homes or any other place they feel like. The flexible place to access the materials is also supported with the flexible time, as the students can access the materials at any time, all day long. Currently, students have their own computers or laptops as well as smartphones or mobile phones. They have unlimited internet access package in their mobile phones or at home. An online learner can quickly establish comfort with the technology, comfort with pre-dominantly text-based communication, and comfort with a higher level of self-direction than in a traditional classroom (CONRAD; DONALDSON, 2011, p. 7-8). 
The recapitulation of the suggestions made by the students for improving the e-learning system is as follows:

- Add some videos or podcasts;

- Give more games in the quizzes;

- Give more time for the quizzes;

- Improve the website system.

Several students gave suggestions about adding more videos or podcast in the materials provided. According to the students, the videos or podcasts will help them understand the materials better. This can be due to the different ways of learning of each student. For visual learners, they can understand the material only by reading the PowerPoint slides. However, for auditory learners, they can comprehend the materials better by listening to the lectures, e.g. listening to the lectures given in videos or podcasts.

Many studentssuggested adding more games in the quizzes. They particularly enjoy the use of crosswords as quizzes. Providing games, such as the crosswords, for the quizzes make them feel more interested in taking the quizzes as it feels like playing instead of just learning. Still related to the quizzes, some students ask for a longer time to take the quizzes. In the quizzes that have been implemented in the e-learning system, the students were given only 15 minutes to complete each quiz. The time allocation seems to be too short for some students who do not have high speed internet access.

Several students complained about the website system. This is related to the university server that hosts the AULA (i.e. the e-learning platform). It is true that the server was down several times due to the overload access. Consequently, when the server was down or under maintenance, students needed to reconnect to the website later.

\section{Conclusion}

Based on the tabulation of the opinions of the students obtained from the open-ended questionnaire, we can see that a majority of the students are satisfied with the e-learning system. They particularly enjoyed the e-learning system because it is fun, easy to access (time and place are flexible), and the materials presented are easy to understand (as they can be more focused on their study, without any distractions from their classmates). A few students who are not satisfied with the e-learning system stated that they need more detailed explanation as well as verbal explanation. For the further implementation of the e-learning system in this department, the lecturers are expected to add more videos or podcasts, add more games in the quizzes, and provide longer time to complete the quizzes. A concern is also addressed to the website system as the university server that hosts the e-learning platform was down several times. Consequently, the management of the university should also assist in ensuring the smooth implementation of the e-learning system in this department. 


\section{References}

ALHARBI, Hael. Traditional versus E-learning language lessons courses: a comparative analysis of student perception and performance through an Arabic language lessons: a case study. Thesis (Doctor of Philosophy) - University of Wollongong, Wollongong, 2012.

ALLEN, I. Elaine; SEAMAN, Jeff. Going the distance: online education in the United States, 2011. Babson: Babson Survey Research Group, 2011. Available at: <http://sloanconsortium.org/publications/survey/ going_distance_2011>.Access: 18 February 2015.

ANDERSON, Terry. Modes of interaction in distance education: recent developments and research questions. In: MOORE, Michael Grahame; ANDERSON. William G. (Ed.). Handbook of distance education. Mahwah: LEA, 2003. p. 129-144.

AWADH, Alqahtani $Y$. The effectiveness of using E-learning, blended learning and traditional learning on students' achievement and attitudes in a course on Islamic culture: an experimental study. (Thesis) Durham University, Durham, 2010.

BENNETT, Neville; WOOD, Liz; ROGERS, Sue. Teaching through play: teachers' thinking and classroom practice. Philadelphia: Open University Press, 1997.

BERSIN, Josh. The blended learning book: best practices, proven methodologies, and lessons learned. San Francisco: John Wiley \& Sons, 2004.

CHICKERING, Arthur W.; EHRMANN, Stephen C. Implementing the seven principles: technology as lever. AAHE Bulletin, v. 49, n. 2, p. 3-6, 1996.

CONRAD, Rita-Marie; DONALDSON, J. Ana (Ed.). Engaging the online learner: activities and resources for creative instruction. San Francisco: John Wiley \& Sons, 2011.

CRESWELL, John W. Research design: qualitative, quantitative, and mixed methods approaches. Thousand Oaks: Sage, 2003.

FREEMAN, Sydney. The future of higher education preparation programs: implications for policy and practice. eJournal of Education Policy, v. 12, p. 1-7, 2012.

HISLOP, Gregory W. Anytime, anyplace learning in an online graduate professional degree program. Group Decision and Negotiation, v. 8, n. 5, p. 385-390, 1999.

KEARSLEY, Greg. Online education: learning and teaching in cyberspace. Belmont: Wadsworth: Thomson Learning, 2000.

KEEGAN, Desmond. The two modes of distance education. The Journal of Open and Distance Learning, v. 13, n. 3, p. 43-47, 1998. 
KEMENDIKBUD. Target 2015, angka partisipasi kasar perguruan tinggi 35 persen. Available at: <http://www. kemdikbud.go.id>. Access: 1 August 2016.

KWARY, Deny Arnos. The comparison between the result of E-learning and traditional learning: a case study on reading IV subject at D-III in English language study program. Airlangga: Airlangga University, 2006. Research paper.

PINKER, Steven. The language instinct: how the mind creates language. New York: Harper Perennial Modern Classics, 2007.

ROSEN, Larry D.; CARRIER, L. Mark; CHEEVER, Nancy A. Rewired: understanding the iGeneration and the way they learn. New York: Macmillan, 2010.

Received on December $8^{\text {th }}, 2016$.

Approved on April 4 2017.

Deny A. Kwary is the head of the English department, faculty of humanities, Airlangga University, Indonesia. He is also the Language Manager of Oxford Indonesian Living Dictionary. He completed his PhD in Lexicography from Aarhus University, Denmark. His research interests include lexicography, corpus linguistics, and English language teaching.

Sarah Fauzie is a research assistant at the English department, faculty of humanities, Airlangga University, Indonesia. She completed her first degree at the same university. Her research interests include general linguistics, business English, and English language teaching. 